\title{
Oestrogen-like effect of genistein on follicle - stimulating hormone release in ovariectomized ewes*
}

\author{
A. Wójcik-Gładysz ${ }^{1}$, K. Romanowicz, T. Misztal and J. Polkowska
}

The Kielanowski Institute of Animal Physiology and Nutrition, Polish Academy of Sciences 05-110, Jabtonna, Poland

(Received 25 July 2006; revised version 4 October 2006; accepted 6 November 2006)

\begin{abstract}
Phytoestrogens, plant-derived oestrogen-like compounds exert numerous effects on the reproductive functions of animals. The present study was designed to demonstrate if exogenous genistein infused during the breeding season into the third ventricle of the brain of ovariectomized (OVX) ewes could affect the follicle stimulating hormone (FSH) release from the pituitary cells. Two year old OVX ewes $(n=8)$ were infused with vehicle (control, $n=3$ ) or genistein $(10 \mu \mathrm{g} / 100 \mu \mathrm{l} / \mathrm{h}, \mathrm{n}=5)$ into the third ventricle. The infusions were done from 10.00 to $14.00 \mathrm{~h}$ and blood samples collection was performed this day from 8.00 up to $20.00 \mathrm{~h}$ and next day from 8.00 to $10.00 \mathrm{~h}$. The animals were slaughtered thereafter. FSH cells in the adenohypophysis were localized by immunohistochemistry. Plasma FSH concentrations were measured by radioimmunoassay. Immunohistochemical analysis revealed that the number of immunoreactive (IR) FSH cells in the adenohypophysis and IR material stored in these cells increased in genistein-infused animals, microscopic observations were confirmed by statistical analysis $(\mathrm{P}<0.001)$. The concentrations of FSH was significantly lower $20 \mathrm{~h}$ after genistein infusions, as compared to the values noted in vehicle infused ewes $(34.18 \pm 1.36$ vs $40.62 \pm 2.69 ; \mathrm{P}<0,05)$, respectively. The presented results demonstrated that genistein could affect the FSH release in the OVX ewes.
\end{abstract}

KEY WORDS: genistein, FSH, ovariectomy, ewes

\section{INTRODUCTION}

Phytoestrogens, plant-derived oestrogen-like compounds, affect the development and physiology of mammals, and especially their reproductive functions (Whitten and Patisaul, 2001). The main source of phytoestrogens are important pasture

\footnotetext{
* Supported by the State Committee for Scientific Research, Grant No. 6 PO6D 01120

${ }^{1}$ Corresponding author: e-mail: a.wojcik@ifzz.pan.pl
} 
and forage plants, e.g., clover, soya bean or lucerne. Although phytoestrogens are partially metabolized by ruminal microorganisms after ingestion, they have been detected in constitutional fluids, i.e. blood plasma and milk, as well as in numerous animal tissues, including the reproductive organs and brain (King et al., 1998). The chemical structure of phytoestrogens is similar to the structure of synthetic oestrogens and it enables to activate $\alpha$ and $\beta$ oestrogen receptors (ER) (Kuiper et al., 1998). Some studies have shown that several isoflavonoids act as oestrogen agonist via ER (e.g., Kuiper et al., 1998). Moreover, genistein, the most important isoflavons, has been shown to have oestrogen-like effects in the female reproductive system of rats (Santell et al., 1997).

Studies performed on ewes have been showed that the phytoestrogens can bind to oestradiol receptors in both the pituitary gland and hypothalamus (Mathieson and Kitts, 1980). In this way, they may interfere with the oestrogen feedback mechanism involved in the regulation of the gonadotrophins release.

Follicle - stimulating hormone (FSH) is primary hormone that regulates follicle development in the female ovaries and spermatogenesis in the male gonads (Padmanabhan and Sharma, 2001). Regulation of FSH synthesis and release is still less recognized than our knowledge concerning luteinizing hormone (LH) secretion. Moreover, in several physiological paradigms secretion of FSH and LH are not regulated coordinally. Oestradiol, in different manner modify expression of the genes encoding LH and FSH subunits and the release of these hormones (Rozell and Keisler, 1990; Padmanabhan and Sharma, 2001). Recently, it has been demonstrated that oestradiol in opposite way alters secretion of FSH and LH from cultured ovine pituitary cells: it inhibited basal secretion of FSH but stimulated basal secretion of LH (Baratta et al., 2002).

As a result of feeding the sheep of diets rich in phytoestrogens, numerous disturbances in reproductive activity were described (Nwannenna et al., 1994, 1995). However, very little is known about the mechanisms causing these disturbances, especially with reference to interactions between phytoestrogens and gonadotrophins secretion on the central nervous system (CNS) level. The studies of Kuiper et al. (1997, 1998) has been shown that genistein effectively competes for both ER $\alpha$ and ER $\beta$ receptors on the level of the CNS. Moreover, our previous works demonstrated the oestrogen-like effect of exogenous genistein on the LH secretion in ovariectomized ewes during both the seasonal anoestrous and breeding season (Romanowicz et al., 2004; Wójcik-Gładysz et al., 2005). On the basis of these observations, we focused our interest on effect of genistein on the release of second gonadotrophin - the FSH. Therefore, using as a model of ovariectomized ewes during the breeding season, the following aspects were considered in response to genistein infused into the third ventricle of the brain: 1. the immunoreactivity of FSH-producing cells, 2. FSH concentration in the peripheral blood plasma before, during and after this infusion. 


\section{MATERIAL AND METHODS}

\section{Animals and management}

The experiment was performed on two years old ovariectomized female sheep (Polish Lowland, $\mathrm{n}=8$ ). The intracerebroventricular (icv) infusions of genistein were done during the breeding season - two months after ovariectomy. The animals were maintained indoor under natural lighting conditions $\left(52^{\circ} \mathrm{N}, 2^{\circ} \mathrm{E}\right)$ and fed a diet of commercial concentrates, with hay and water available ad libitum.

Stainless steel guide cannulae (1.2 mm OD) were implanted into the third ventricle of the brain under general anaesthesia, following the stereotaxic procedure described by Traczyk and Przekop (1963). The guide cannula was fixed to the skull with stainless steel screws and dental cement. The external opening to the canal was closed with a stainless steel cap. The placement of guide cannula was confirmed by the outflow of a small amount of cerebro-spinal fluid during the surgery and after slaughtering by the infusion of a small volume of blue ink. One day before the infusion a jugular venous catheter was inserted into each sheep and kept with heparinized saline (50 units heparin $/ \mathrm{ml}$ in $0.9 \% \mathrm{w} / \mathrm{v} \mathrm{NaCl}$ ).

\section{Infusion procedure and blood sampling}

Animals were randomly divided into two groups: 1 . the control group $(\mathrm{n}=3)$ infused icv with Ringer-Lock'e solution $(100 \mu \mathrm{l} / \mathrm{h})$ and 2 . the experimental group $(\mathrm{n}=5)$ - infused icv with genistein (Sigma) $10 \mu \mathrm{g} / 100 \mu \mathrm{l} / \mathrm{h}$. This dose was selected according to our previous study (Wójcik-Gładysz et al., 2005). Genistein was dissolved in ethanol $(1 \mathrm{mg} / 0.5 \mathrm{ml})$ and stored at $-20^{\circ} \mathrm{C}$ as a stock solution. On the day of infusion, it was diluted in $2 \mathrm{ml}$ of saline. Immediately before each infusion, the stilette was removed from the guide cannula. The injector needle, connected to a length of tubing (Hythe, Kent, England) containing the test solution, was lowered to a depth of approximately $2.5 \mathrm{~mm}$ above the base of the brain at the level of the medial basal hypothalamus. Infusions were applied from 10.00 to $14.00 \mathrm{~h}$, at a flow rate of $1.67 \mu \mathrm{l} / \mathrm{min}$, using calibrated $1.0 \mathrm{ml}$ gas-tight syringes and a microinjection pump CMA/100 (CMA/Microdialysis AB, Stockholm, Sweden). Blood samples were collected on the day of infusion at 10 min intervals, from 8.00 to $20.00 \mathrm{~h}$ (Day 1). Sampling was continued also on the next morning from 8.00 to $10.00 \mathrm{~h}$ (Day 2). Samples were centrifuged and plasma was stored at $-20^{\circ} \mathrm{C}$ until analysis. Sheep were slaughtered $24 \mathrm{~h}$ after beginning of the infusion by decapitation under pentobarbital anaesthesia in the local abattoir. During serious of sampling and infusion animals were kept in comfortable cages where they could lie down and had unrestrained access to hay. All described procedures were approved by the 
Local Ethics Committee at the Warsaw Agriculture University (opinion number $-31 / 2001)$.

\section{Immunohistochemistry}

Immediately after decapitation, each brain was perfused via both carotid arteries with $1500 \mathrm{ml} 0.1 \mathrm{M}$ phosphate buffered saline (PBS) and subsequently with $2000 \mathrm{ml} 0.1 \mathrm{M}$ PBS containing 4\% (w/v) paraformaldehyde and $15 \%$ saturated picric acid solution (w/v), $\mathrm{pH}$ 7.4. The pituitaries were dissected 20 min after the beginning of perfusion and postfixed for $48 \mathrm{~h}$ by immersion in the same fixative. All pituitaries were washed with 0.01 M PBS ( $\mathrm{pH} 7.4$ ), dehydrated in graded alcohols, embedded in paraplast and then cut in the sagittal plane at $3 \mu \mathrm{m}$ and processed for immunohistochemistry. All sections were washed in 0.01 M PBS and then incubated for $30 \mathrm{~min}$ in $0.1 \%$ hydrogen peroxide in $0.01 \mathrm{M}$ PBS and 30 min in $2 \%$ preimmune lamb serum in $0.01 \mathrm{M}$ PBS. The sections were incubated with primary antisera: anti-oFSH $\beta$ no. P5 diluted 1:200 for $48 \mathrm{~h}$ at $4{ }^{\circ} \mathrm{C}$ (HurbainKosmath et al., 1990). The sections were rinsed in PBS and incubated for $2 \mathrm{~h}$ at room temperature with secondary antibody (sheep anti-rabbit $\mathrm{Ig}[\mathrm{H}+\mathrm{L}]$ labelled with peroxidase; Institute Pasteur, Paris, France), at a dilution 1: 40 in $0.1 \%$ normal lamb serum in PBS. The colour reaction was developed by incubating sections with $0.05 \%$ 3'3-diaminobenzidine tetrachloride chromogen (Sigma) and 0.001\% hydrogen peroxide in $0.05 \mathrm{M}$ Tris buffer. As a control reaction, the inhibition of anti-hormone serum with its homologous antigen was used. Preincubation of the FSH antisera with $4 \mu \mathrm{g} / \mathrm{ml}$ synthetic rFSH32V02 (National Hormone and Peptide Program, Torrance, California, USA) blocked the immunostaining. Antigens and antisera were mixed and pre-incubated for $24 \mathrm{~h}$ at $4{ }^{\circ} \mathrm{C}$ before being used. Both control staining did not exhibit any specific staining (data not shown).

\section{Image and statistical analyses}

A projection microscope Nikon type 104 (Nikon Corporation, Yokohama, Japan) was used to analyse pituitary sections. Staining was analysed using image analysis computer system "Lucia” version 3.51ab (Laboratory Imaging Ltd., Prague, Czech Republic). Immunostained sections were projected by camera (Panasonic KR222, Matsushita Electric Industrial Co., Osaka, Japan) to a colour monitor. Pictures were adjusted for optimal contrast, fixed at the same brightness levels and saved in buffering system. The analyses for statistical purposes were performed for the pituitary sections with an $\times 40$ objective. Two parameters, 1 . area fraction (percentage of total area that exhibited positive staining, indicates percent of stained cells), and 2. integral density (the sum of individual optical densities of 
each pixel in the area being measured, indicates the amount of substance in tissue sections, expressed in relative units) were analysed for adenohypophyseal cells expressing immunoreactive FSH $\beta$ subunits. Quantitative analysis was performed for each pituitary gland in the subarea of adenohypophysis using threshold function to select a range of gray values that was identified as positive staining. All other values were referred to as nonstaining. Before measurements, the images were processed by substraction of background and removal of artefacts. Frame size was kept constant for the duration of the image analysis. The analyses of immunoreacted cells were made in the 4 sections of each adenohypophysis, using every $40^{\text {th }}$ mounted and stained sections (16 fields of $0.05595 \mathrm{~mm}^{2}$ measured in each section). The data from sections were averaged to obtain a mean estimate for each adenohypophysis within each animal. Then, the mean data were pooled to represent genistein - or vehicle solution-treatment groups. The data were analysed by non-parametric Walda-Wolfowitz test using Statistica ${ }^{\text {TM}}$ PL computer program (StatSoft ${ }^{\circledR}$ Kraków, Poland). The data are reported as the mean percentage \pm SD of the total area that exhibited positive staining and mean relative units \pm SD of integral density. Significance was defined at the $\mathrm{P}<0.001$ levels.

\section{Determination of FSH in peripheral blood plasma and statistical analyses}

The concentration of FSH was determined by routine double antibody radioimmunoassay (RIA), using anti ovine-FSH (teri. anti-oFSH) and anti rabbitgammaglobulin antisera. The anti-FSH, as well as the FSH standard (teri. oFSH-and teri. FSH ig) was kindly supplied by Dr. L.E. Reichert Jr. (Tucker Endocrine Research Institute LLC, Atlanta, Georgia, USA). The assay sensitivity was $1.56 \mathrm{ng} / \mathrm{ml}$ and the intra- and inter assay coefficients of variation were $3.3 \pm 1.5$ and $11.3 \pm 2.2 \%$, respectively. The effect of treatments on FSH concentrations was analysed by the one-way analysis of variation (ANOVA) followed by the least significant differences test using Stastistica TM PL computer program (StatSoft ${ }^{\circledR}$ Kraków, Poland). Data are presented as mean \pm SEM.

\section{RESULTS}

Immunoreactivity of FSH-cells

The number of cells stained positively for the presence of $\operatorname{FSH} \beta$ and the intensity of the immunostaining increased in sheep infused with genistein comparing to those infused with vehicle solution (Figure $1 \mathrm{a}, \mathrm{b}$ ). This was 


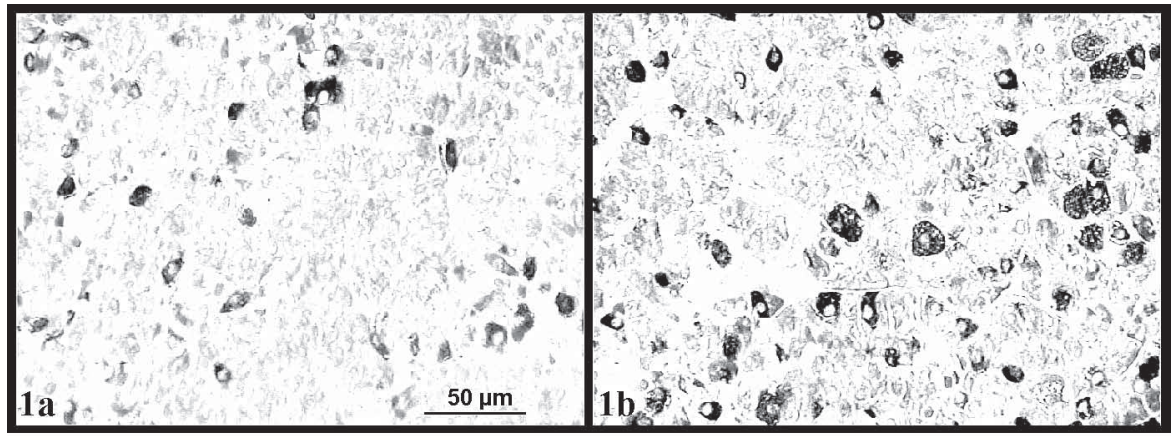

Figure 1. Immunoreactive (IR) FSH-cells a,b in the adenohypophysis of a representative OVX ewes from vehicle a. and genistein b. infused groups. Scale bars, $50 \mu \mathrm{m}$. Note: The increase in the number of labelled FSH-cells and content of IR FSH $\beta$ material after genistein infusions

reflected by the significant increase $(\mathrm{P}<0.001)$ in the percentage of area occupied by FSH-producing cells and the density of immunoreactive material within the adenohypophysis of genistein-infused ewes compared to the vehicle infused ones (Figure $2 \mathrm{a}, \mathrm{b}$ ).
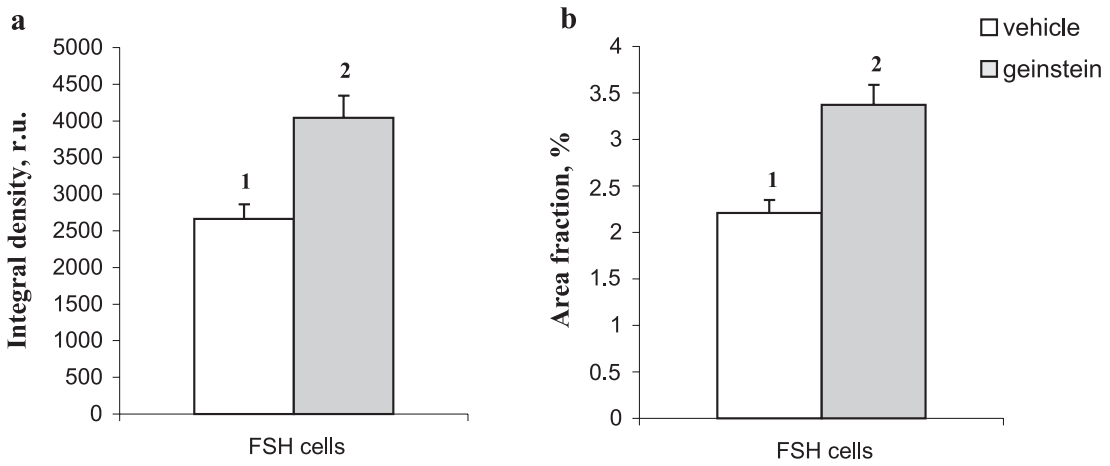

Figure 2. Integral density (relative units) for IR FSH $\beta$ in the pituitary cells (a) and percentage of total area exhibiting positive staining (area fraction - \%) for IR FSH (b) of ewes after vehicle and genistein infusions to the third ventricle of the brain means \pm SD with typescripts $\left({ }^{1,2}\right)$ differ at $\mathrm{P}<0.001$

\section{Hormonal measurements}

No significant difference in the plasma concentration of FSH was observed during two $\mathrm{h}$ before infusions between the experimental and control group 
FSH level Day 1

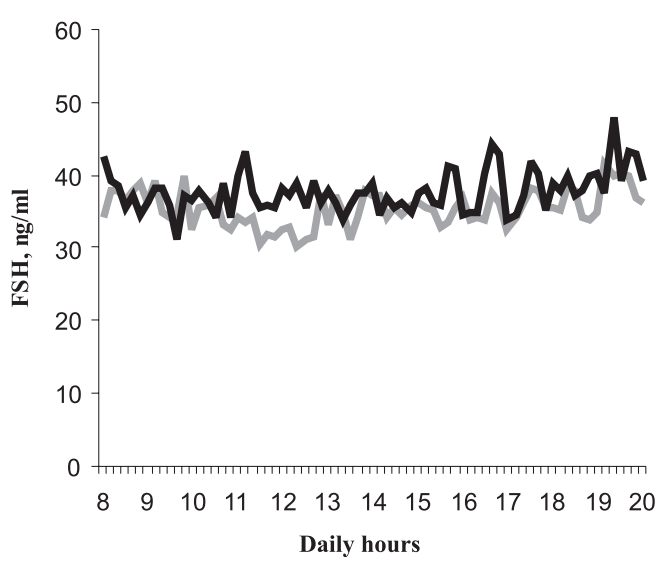

FSH level Day 2

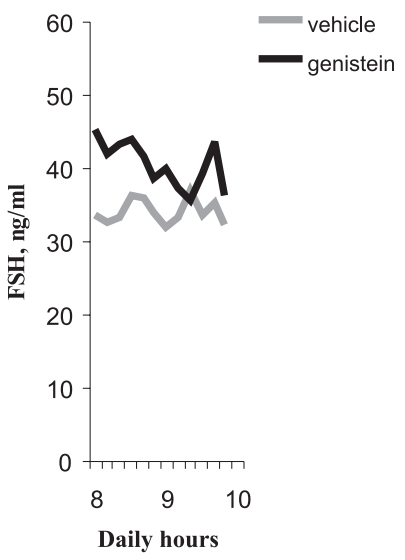

Figure 3. Patterns of FSH secretion in two representative OVX ewes at Day 1 and Day 2 of the experiment following vehicle or genistein infusion

$(36.94 \pm 1.88$ vs $37.64 \pm 3.18 \mathrm{ng} / \mathrm{ml})$. Infusion of genistein caused visible but not significant decrease in FSH concentration in the experimental group compared to the values observed in control one. Plasma FSH concentration reached significantly lower level in genistein treated ewes $24 \mathrm{~h}$ after the infusion, compared to the controls (Day 2): $34.18 \pm 1.36$ vs $40.62 \pm 2.69 \mathrm{ng} / \mathrm{ml}(\mathrm{P}<0.05)$. The representative pattern of FSH secretion in two OVX ewes infused with vehicle or genistein during the entire experimental period is shown on the Figure 3.

\section{DISCUSSION}

The results of the present study show that genistein affects the release of FSH in ovariectomized ewes, following infusion into the third ventricle of the brain. The increase in the number of FSH cells and the increased contents of IR FSH material in these cells after genistein infusions can be explained by restraining of release of this hormone into the peripheral circulation. This is supported by a lowering FSH plasma level in genistein-treated ewes, sustained until the second day of the experiment.

This effect of genistein on FSH secretion in sheep is similar to the action of oestradiol shown in in vivo and in vitro studies (Henderson et al., 1989). Oestradiol infusions in OVX ewes (Rozzel and Keisler, 1990) or in non-operated ewes 
during the breeding season (Baird et al., 1981) caused the decrease in FSH basal secretion. The decrease in the basal FSH secretion from ovine pituitary cells was also observed when pituitary cell cultures were exposed to oestradiol in study performed in vitro by Huang and Miller (1980).

The effect of genistein infusion on the FSH release observed in the present study seems to be opposite to that exerted by this phytoestrogen on the LH release, described earlier by Wójcik-Gładysz et al. (2005). ICV infusion of genistein in OVX ewes elicited enhancement of LH release to the blood circulation. Taking together, these data agree with the results of Rozzell and Keisler (1990), who showed an opposite pattern of the secretion of FSH and LH in the ovariectomized ewes in response to the injection of oestradiol. Other investigators also found suppression ofFSH concurrent with stimulation of LH in long-term ovariectomized ewes given an injection (Elssaser et al., 1983) or implants (Clarke et al., 1989) of oestradiol. On the basis of above information, it seems that genistein, elicits the oestrogen-like effect on the FSH secretion processes (Kuiper et al., 1998; Skynner et al., 1999; Hrabovszky et al., 2000).

The early study of Padmanabhan et al. (1997) clearly demonstrated the existence of a dual mode of FSH secretion: tonic (basal secretion) and episodic, which includes both GnRH-associated and non-GnRH-associated episodes of FSH secretion. The cited authors suggested that unlike LH, which is secreted primarily in pulses, the predominant mode of FSH secretion is basal. It is however difficult to decipher secretory patterns of FSH from peripheral hormone measurements, because of the molecular heterogeneity and the long half-life of FSH in the peripheral circulation (Padmanabhan et al., 1999). The presented central effect of genistein on FSH secretion in ewes could indeed include the action of this phytoestrogen at the CNS level. Such effect could be exerted indirectly via neurotransmitters that control GnRH release (Caraty et al., 1989) and /or directly on the GnRH neurons. The latest study of Skinner and Dufourny (2005) demonstrated the localization of ER $\beta$ on the GnRH neurons in the hypothalamus of this species. Over $50 \%$ of the GnRH neurons were found to express immunoreactive ER $\beta$, although the functional significance of these ER $\beta$ remains to be determined. It is worthy to note that genistein poses a high binding affinity for ER $\beta$ (Kuiper et al., 1998; Skynner et al., 1999; Hrabovszky et al., 2000). However, the other modulatory action of this phytoestrogen, especially at the level of the pituitary gland, can not be excluded.

Some studies demonstrated that in the regulation of the FSH synthesis and release are involved the intrapituitary, paracrine-acting factors (Padmanabhan and Sharma, 2001; Nett et al., 2002). Key candidates for such endocrine or local paracrine action are inhibin and activin, members of the TGF $\beta$ family, and follistatin, a binding neutralizer of activin (Roberts et al., 1989; Mather et al., 
1993). These regulators modulate FSH synthesis and consequently affects basal FSH release. Inhibin and follistatin inhibit FSH, and activin stimulates FSH production (Ying, 1988). Contrary to early beliefs that activins, inhibins and follistatins are produced only at the gonadal level and act in an endocrine manner, more recent studies have shown that these regulatory proteins are also expressed at the pituitary level and can act in an autocrine/paracrine manner to regulate FSH secretion (see review by Padmanabhan and Sharma, 2001). Nett et al. (2002), utilizing cultured pituitary cells, demonstrated that oestradiol induced increase in secretion of LH but resulted in decrease in the secretion of FSH. The cited authors (Nett et al., 2002) indicated, that inhibitory effect of oestradiol on secretion of FSH appears to be mediated by its ability to suppress the expression of the gene encoding activin thus by inhibiting production of activin. Although we did not studied the changes in expression of the steroid hormone-related proteins (activin, inhibin), the presented, long-lasting effect of genistein on FSH secretion seems to be exerted indirectly at the pituitary gland level.

Summarizing, genistein, a phytoestrogen, could interfere with the normal oestrogen feedback mechanism with reference to the release of gonadotropins in the ewe but the exact mechanism of its action on the GnRH neurons and/or the pituitary gonadotrophs cannot be fully accounted for and needs further investigations. In case of FSH secretion, the present results demonstrated that genistein could exert the oestrogen-like effect in the OVX ewes.

\section{REFERENCES}

Baird D.T., Swatson I.A., McNeilly A.S., 1981. Relationship between LH, FSH and prolactin concentration and the secretion of androgens and estrogens by the preovulatory follicle in the ewe. Biol. Reprod. 24, 1013-1025

Baratta M., West L.A., Turzillo A.M., Nett T.M., 2002. Activin modulates differential effects of estradiol on synthesis and secrection of follicule-stimulating hormone in the ovine pituitary cells. Biol. Reprod. 64, 714-719

Caraty A., Fabre-Nys C., Delaleu B., Locatelli A., Bruneau G., Karsch F.J., Herbison A., 1989. Evidence that the mediobasal hypothalamus is the primary site of action of estradiol in inducing the preovulatory gonadotropin releasing hormone surge in the ewe. Endocrinology 139, 17521760

Clarke I.L., Cummins J.T., Crowder M.E., Nett T.M., 1989. Long-term negative feedback effects of oestrogen and progesterone on the pituitary gland of the long-term ovariectomized ewe. J. Endocrinol. 120, 207-214

Elsasser T.H., Bolt D.J., Bradley B.D., Roper M., 1983. Luteinizing hormone, follicle-stimulating hormone and prolactin secretion in ewes and wethers after zeranol or estradiol secretion. J. Anim. Sci. 57, 443-448

Henderson K.M., Ellen R.L., Savage L.C., McNetty K.P., 1989. Studies of effectiveness of gonadotrophin-releasing hormone, steroids and follicular fluid in modulating ovine gonadotrophin output in vivo and in vitro. J. Reprod. Fertil. 86, 105-117 
Hrabovszky E., Shughrue P.J., Merchenthaler I., Hajszan T., Carpenter C.D., Liposits Z., Petersen S.L., 2000. Detection of estrogen receptor-beta messenger ribonucleic acid and ${ }^{125}$ I-estrogen binding sites in luteinizing hormone-releasing hormone neurons of the rat brain. Endocrinology 141, 3506-3509

Huang E.S., Miller W.L., 1980. Effects of estradiol-17ß on basal and luteinizing hormone releasing hormone-induced secretion of luteinizing hormone and follicle stimulating hormone by ovine pituitary cell culture. Biol. Reprod. 23, 124-134

Hurbain-Kosmath I., Berault A., Noel N., Polkowska J., Bohin A., Jutisz M., Leiter E.H., Beamer W.G., Bedigian H.G., Davisson M.T., Harrison D.E., 1990. Gonadotropes in a novel rat pituitary tumor cell line, RC-4B/C. Establishment and partial characterization of the cell line. In Vitro Cell. Dev. Biol. Anim. 26, 431-440

King R.A., Mano M.M., Head R.J., 1998. Assesment of isoflawoid concentrations in Australian bovine milk samples. J. Dairy Res. 65, 479-489

Kuiper G.G.J.M., Carlsson B., Grandien K., Enmark E., Haggbland J., Nilsson S., Gustfsson J.-A., 1997. Comparison of the ligand binding specificity and transcript tissue distribution of estrogen receptors $\alpha$ and $\beta$. Endocrinology 138, 863-870

Kuiper G.G.J.M., Lemmen J.G., Carlsson B., Corton J.C., Safe S.H., van der Saag P.T., van der Burg B., Gustafsson J.A., 1998. Interaction of estrogenic chemicals and phytoestrogens with estrogen receptor $\beta$. Endocrinology 139, 4252-4263

Mather J.P., Roberts P.E., Krumen L.A., 1993. Follistatin modulates activin activity in cell- and tissue-specific manner. Endocrinology 132, 2732-2734

Mathieson R.A., Kitts W.D., 1980. Binding of phyto-oestrogen and oestradiol-17 beta by cytoplasmic receptors in the pituitary gland and hypothalamus of the ewe. J. Endocrinol. 85, 317-325

Nett T. M., Turzillo A.M., Baratta M., Rispoli L.A., 2002. Pituitary effects of steroid hormones on secretion of follicle-stimulating hormone and luteinizing hormone. Domest. Anim. Endocrinol. $5391,1-10$

Nwannenna A., Lundh T.J.-O., Madej A., Fredriksson G., Bjornhag G., 1995. Clinical changes in ovariectomized ewes exposed to phytoestrogens and oestradiol-17 $\beta$ implants. Proc. Soc. Exp. Biol. Med. 208, 92-97

Nwannenna A., Madej A., Lundh T.J.-O., Fredriksson G., 1994. Effects of oestrogenic silage on some clinical and endocrinological parameters in ovariectomized heifers. Acta Vet. Scand. 35, 173-183

Padmanabhan V., Lee J.S., Beitins I.Z., 1999. Follicle-stimulating isohormones: regulation and biological significance. J. Reprod. Fertil., Suppl. 54, 87-99

Padmanabhan V., McFadden K., Mauger D.T., Karsch F.J., Midgley Jr. A.R., 1997. Neuroendocrine control of FSH secretion. I. Direct evidence for separate episodic and basal components of FSH secretion. Endocrinology 138, 424-432

Padmanabhan V., Sharma T.P., 2001. Neuroendocrine vs. paracrine control of follicle-stimulating hormone. Arch. Med. Res. 32, 533-543

Roberts V., Meunier H., Vaughan J., Rivier J., Rivier C., Vale W., Sawchenko P., 1989. Production and regulation of inhibin subunits in pituitary gonadotropes. Endocrinology 124, 552-554

Romanowicz K., Misztal T., Barcikowski B., 2004. Genistein, a phytoestrogen, effectively modulates luteinizing hormone and prolactin secretion in ovariectomized ewes during seasonal anoestrus. Neuroendocrinology 79, 73-81

Rozell T.G., Keisler D.H., 1990. Effects of estradiol on LH, FSH and prolactin in ovariectomized ewes. J. Reprod. Fertil. 88, 645-653

Santell R.C., Chang Y.C., Nair M.G., Helferich W.G., 1997. Dietary genistein exerts estrogenic effects upon the uterus, mammary gland, and the hypothalami/pituitary axis in rats. J. Nutr. 127, 263-269 
Skinner D.C., Dufourny L., 2005. Oestrogen receptor $\beta$-immunoreactive neurons in the ovine hypothalamus: distribution and colocalisation with gonadotropin-releasing hormone. J. Neuroendocrinol. 17, 29-39

Skynner M.J., Sim J.A., Herbison A.E., 1999. Detection of estrogen receptor $\alpha$ and $\beta$ messenger ribonucleic acids in adult gonadotropin-releasing hormone neurons. Endocrinology 140, 51955201

Traczyk W., Przekop F., 1963. Methods of investigation of the function of the hypothalamus and hypophysis in chronic experiments in sheep. Acta Physiol. Pol. 14, 217-226

Whitten P.L., Patisaul H.B., 2001. Cross-species and interassay comparisons of phytoestrogen action. Environ. Health Perspect. 109, 5-20

Wójcik-Gładysz A., Romanowicz K., Misztal T., Polkowska J., Barcikowski B., 2005. Effects of intracerebroventricular infusion of genistein on the secretory activity of the GnRH/LH axis in ovariectomized ewes. Anim. Reprod. Sci. 86, 221-235

Ying S.Y., 1988. Inhibins, activins and follistatins: gonadal proteins modulating the secretion of follicule-stimulating hormone. Endocrine Rev. 9, 267-278 